\title{
ANCAMAN KEAMANAN NASIONAL DI WILAYAH PERBATASAN INDONESIA: STUDI KASUS PULAU SEBATIK DAN TAWAU (INDONESIA-MALAYSIA)
}

\author{
Chairil Nur Siregar ${ }^{1}$, Sutiadi Rahmansyah ${ }^{2}$, Epin Saepudin ${ }^{3}$ \\ ${ }^{1}$ Fakultas Seni Rupa dan Desain, Institut Teknologi Bandung \\ ril_gar@yahoo.com
}

\begin{abstract}
ABSTRAK
Artikel ini meneliti tentang ancaman keamanan nasional di wilayah perbatasan Indonesia-Malaysia khususnya di pulau Sebatik. Metode yang digunakan dalam penelitian ini ialah metode deskriptif kualitatif dengan menggunakan beberapa teknik dalam pengambilan datanya, yaitu wawancara, observasi, studi dokumentasi, dan focus group discussion. Data diperoleh dari lapangan di Perbatasan Republik Indonesia dengan Malaysia di Pulau Sebatik. Lebih spesifik penelitian dilakukan di Desa Aji Kuning Kecamatan Sebatik Tengah dan Tawau (Malaysia). Hasil penelitian menunjukkan ada tiga ancaman ketahanan nasional yang harus dihadapi oleh pemerintah dan masyarakat Indonesia. Ketiga ancaman itu ialah Ketiga ancaman itu ialah ancaman bidang pertahanan dan keamanan atau ancaman militer, ancaman ekonomi, dan ancaman ideologi. Ancaman terhadap bidang pertahanan dan keamanan mencakup tingginya penyelundupan narkotika terutama melalui jalur-jalur tikus, hal ini terjadi karena minimnya pengawasan yang disebabkan kurangnya jumlah personil keamanan (TNI dan Polri) yang bertugas di wilayah perbatasan. Ancaman terhadap ekonomi terjadi karena pemerintah belum sepenuhnya berpihak pada wilayah perbatasan di Pulau Sebatik, sehingga untuk memenuhi kebutuhan hidup sehari-hari, masyarakat masih bergantung ke Malaysia. Ancaman berikutnya ialah ancaman ideologi berkaitan dengan ideologi, potensi lunturnya kebanggaan dan nasionalisme terhadap Indonesia di daerah perbatasan sangat tinggi. Hal ini disebabkan karena tingginya desakan kebutuhan ekonomi yang mendorong para pekerja dari Indonesia untuk berbondong-bondong pindah ke Malaysia, karena secara ekonomi Malaysia lebih menggiurkan dibandingkan Indonesia sehingga banyak orang Indonesia yang berpindah warga negara menjadi warga Malaysia.
\end{abstract}

Kata kunci: Ancaman, Keamanan Nasional, Perbatasan, Indonesia, Malaysia

\begin{abstract}
This article examines national security threats in the Indonesia-Malaysia border, especially on Sebatik Island. The method used in this research is a qualitative descriptive method using several techniques in collecting the data such as interviews, observation, documentation studies, and focus group discussions. Data was obtained from the border area of the Republic of Indonesia with Malaysia on Sebatik Island. It was conducted in Desa Aji Kuning, Sebatik Tengah and Tawau (Malaysia). The results showed that there were three national security threats that must be addressed by Indonesian government and Indonesian society. Those three threats are the threat of security and defense/military threats, economic threats, and ideological threats. Threats to the security and defense sectors include the high number of narcotics smuggling mainly through invisible routes on the border. This was happened due to the lack of supervision and the lack of security personnel (Indonesian Army and Police (TNI and Polri)) serving in the border area. The economy threat occurs because the Indonesian government has not fully supported the society living in the border region on Sebatik Island. In order to meet the daily needs, people are still dependent on Malaysia. The last threat is the ideology threat, there is a big potential for Indonesian living in the border to loss their pride and nasionalism to their country. This happens due to the high economic demand that encourages Indonesian to flock to Malaysia, because Malaysia is more lucrative than Indonesia. This also makes so many Indonesians to move their nationality to become Malaysians.
\end{abstract}

Keywords: Threats, National Security, Borders, Indonesia, Malaysia

2. Fakultas Seni Rupa dan Desain, Institut Teknologi Bandung traveler14@gmail.com

3. Fakultas Seni Rupa dan Desain, Institut Teknologi Bandung celongsocrates@gmail.com 


\section{PENDAHULUAN}

Indonesia dikenal di dunia sebagai negara kepulauan terbesar ke-empat dengan 13.000 pulau dan memiliki populasi lebih dari 200 juta jiwa. Posisi Indonesia berbatasan dengan Negaranegara lain di Asia Tenggara, yaitu Malaysia, Singapura, Timor Leste, Filipina, Australia Papua Nugini, Kepulauan Andaman dan Nikobar. Wilayah perbatasan negara Indonesia dengan wilayah-wilayah tersebut ada yang dipisahkan dengan lautan, ada juga yang terpisah oleh daratan. Hal ini memberikan dampak yang positif dan negatif bagi Indonesia. Dampak positifnya ialah Indonesia mampu dengan mudah melakukan kerjasama di segala bidang dengan negara-negara yang berbatasan dengan Indonesia. Namun dampak negatifnya ialah dengan banyaknya wilayah perbatasan berarti bahwa Indonesia harus mampu juga secara matang menjaga dan melindungi perbatasannya dari hal-hal yang tidak diharapkan. Wilayah perbatasan cenderung mudah memicu terjadinya konflik atau bahkan sengketa wilayah antar Negara.

Konflik dan sengketa yang sering terjadi ialah antara Indonesia dan Malaysia. Konflik antara Indonesia dan Malaysia ini bukan hal yang baru. Hal ini sudah terjadi sejak tahun 1963. Hal ini pula yang menyebabkan Indonesia pada waktu itu memutuskan untuk keluar dari keanggotaan PBB. Soekarno yang merupakan presiden pertama Indonesia pada waktu itupun geram dengan Malaysia dan tak segan untuk mengeluarkan jargon "Ganyang Malaysia". Sejak itu, konflik antara Indonesia dan Malaysia terus berlanjut mulai dengan klaim Malaysia atas budaya Indonesia, seperti halnya klaim atas lagu rasa sayange dan klaim atas budaya reog ponorogo hingga klaim Malaysia atas kepulauan Indonesia, yang menimbulkan kerugian besar bagi pihak Indonesia, yaitu lepasnya kepemilikan Indonesia atas pulau Sipadan dan Ligitan.

Negara menurut Thomas Hobbes berperan penting untuk mempertahankan dan melindungi masyarakatnya dari invasi asing berikut dengan kerusakan-kerusakan atau konflik antar sesama (Buzan, 1983). Hal ini berarti bahwa negara memiliki dua tugas utama yaitu: 1) secara eksternal negara memiliki kewajiban untuk tetap siaga dalam menghadapi segala ancaman dan tantangan dari luar dan 2) dan secara internal negara memiliki kewajiban untuk tetap siaga dalam mengatasi dan melindungi masyarakat dari potensi-potensi terjadinya konflik.

Artikel ini mencoba menggali sejauh mana ancaman pertahanan keamanan di perbatasan darat antara Indonesia dan Malaysia tepatnya di wilayah Sebatik. Sebatik merupakan salah satu pulau milik Indonesia yang terletak dibagian Utara Kabupaten Nunukan, Propinsi Kalimantan Utara. Pulau ini unik, karena pulau ini merupakan wilayah yang berbatasan secara langsung dengan Malaysia. Penelitian ini mencoba menjabarkan ancaman-ancaman keamanan di wilayah 
perbatasan Republik Indonesia dan Malaysia di Pulau Sebatik yang tercakup di dalam dua rumusan masalah sebagai berikut.

1) Apa saja ancaman-ancaman ketahanan nasional yang dapat terjadi di wilayah perbatasan Republik Indonesia dan Malaysia khususnya di wilayah perbatasan di Pulau Sebatik?

2) Bagaimana gambaran kondisi keamanan wilayah perbatasan Republik Indonesia dan Malaysia di Pulau Sebatik?

\section{METODE PENELITIAN}

Penelitian ini menggunakan metode kualitatif. Hal ini dilakukan karena metode kualitatif adalah metode yang tepat untuk mennetukan unsur-unsur pokok sesuai dengan rumusan masalah, tujuan dan manfaat penelitian (Sugiyono, 2005). Selain itu, penelitian kualitatif ini diikuti dengan metode observasi yaitu melakukan observasi secara langsung di lapangan untuk menggali data yang aktual (Marshall dikutip dalam Sugiyono, 2015). Penelitian ini diawali tim dengan mengurai lebih jauh mengenai peta permasalahan yang terjadi di lapangan. Berangkat dari peta masalah yang telah berhasil dirancang, pada tahap ini Tim peneliti merancang instrumen penelitian selaras dengan rumusan masalah yang diajukan. Instrumen penelitian yang digunakan antara lain; pedoman wawancara, pedoman studi dokumentasi, dan pedoman observasi. Pada tahap ini, tim peneliti melakukan pengumpulan data-data yang diperlukan untuk membedah masalah penelitian, baik melalui wawancara, observasi, studi dokumentasi, maupun focus group discussion. Setelah data terkumpul, peneliti kemudian akan melakukan analisis terhadap temuan-temuan penelitian dengan menggunakan konsep, teori, dan pendekatan yang relevan dengan masalah penelitian.

Pengumpulan data dilakukan dengan empat teknik, yakni; wawancara, observasi, studi dokumentasi, dan focus group discussion. Kesatu, pengumpulan data melalui wawancara secara langsung dilakukan terhadap masyarakat yang ada di wilayah perbatasan, baik yang ada di Republik Indonesia maupun yang ada di Malaysia. Kedua, pengumpulan data melalui observasi dimaksudkan untuk memperoleh data yang lebih faktual dan objektif atas masalah penelitian. Observasi ditujukan pada beberapa aspek, antara lain; (1) infrastruktur di wilayah perbatasan, (2) interaksi sosial dalam kehidupan masyarakat, (3) kondisi sosial ekonomi masyarakat wilayah perbatasan, serta (4) aktivitas pertahanan dan keamanan yang dilakukan oleh Tentara Nasional Indonesia dan aparat kepolisian di wilayah perbatasan Ketiga, pengumpulan data melalui studi dokumentasi dilakukan dengan cara mengkaji dokumendokumen laporan kinerja pemerintah daerah, baik berupa Rencana Pembangunan Jangka 
Menengah dan Jangka Panjang, Rencana Tata Ruang dan Wilayah, dan lain sebagainya. Keempat, pengumpulan data melalui focus group discussion dilakukan bersama para pakar pada bidang-bidang yang relevan dengan penelitian, serta pada stakeholders yang membidani persoalan perbatasan, seperti; Kepolisian Republik Indonesia dan Tentara Nasional Indonesia.

Penelitian ini dilaksanakan di Perbatasan Republik Indonesia dengan Malaysia di Pulau Sebatik. Lebih spesifik penelitian dilakukan di Desa Aji Kuning Kecamatan Sebatik Tengah dan Tawau (Malaysia). Objek dalam penelitian ini terdiri dari masyarakat, Kepolisian Resort Kabupaten Nunukan, Kepolisian Sektor Sebatik Timur, Kepolisian Sub Sektor Sebatik Tengah, dan Konsulat Republik Indonesia di Tawau Malaysia. Penelitian ini dilakukan selama satu minggu di minggu kedua September 2019.

\section{KERANGKA TEORI/KONSEP}

\section{A. Letak Geografis Pulau Sebatik}

Secara Geografis, Pulau Sebatik luasnya ialah $433,84 \mathrm{~km}^{2}$, pulau tersebut berada di dua wilayah negara seperti yang dapat dilihat pada gambar berikut:

Gambar 1. Foto Peta Pulau Sebatik

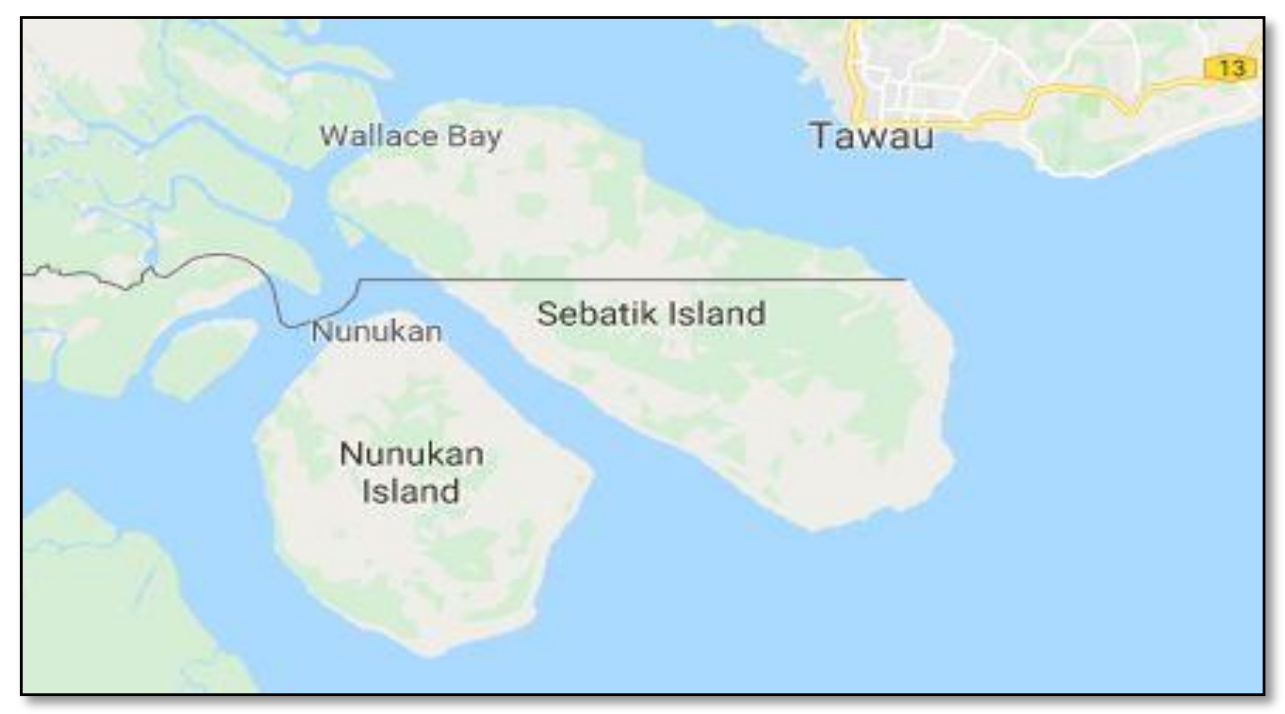

Sumber: https://www.google.com/maps/@4.1516966,117.6288151,10z (diakses 20 september 2019)

Bagian utara Sebatik termasuk ke dalam wilayah milik Malaysia yang luasnya adalah 187,23 $\mathrm{km}^{2}$, dan bagian Selatan pulau ini adalah milik Indonesia dengan luas sekitar 246,61 $\mathrm{km}^{2}$. Pulau Sebatik memiliki lima kecamatan, yaitu: Sebatik Timur, Sebatik Barat, Sebatik (Induk), Sebatik 
Tengah, dan Sebatik Utara. Pembagian kecamatan yang berada di Pulau Sebatik dapat dilihat pada tabel berikut:

Gambar 2. Wilayah Administratif Kecamatan di Pulau Sebatik

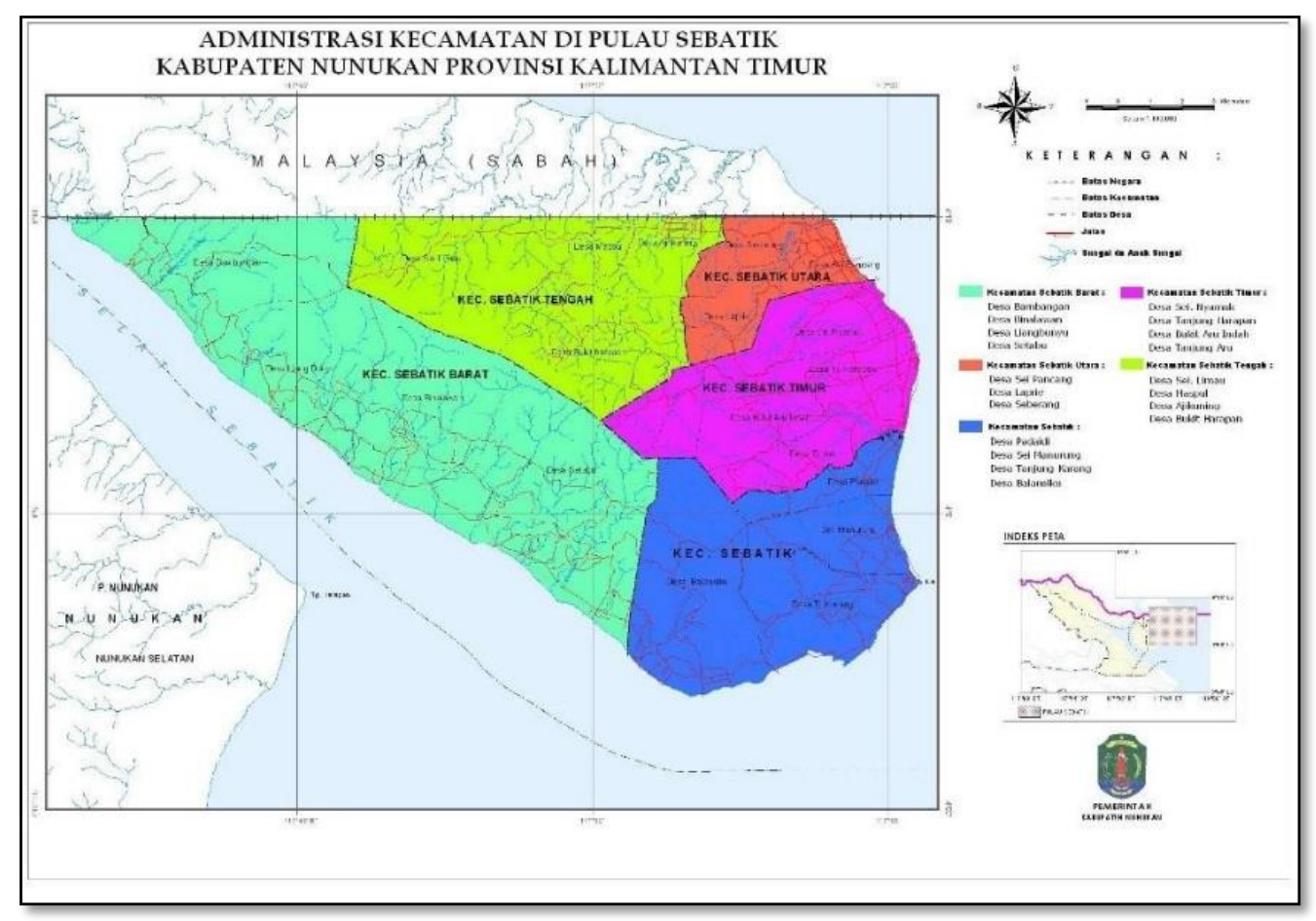

Sumber: https://www.harman.id/detailpost/refleksi-sewindu-usia-kecamatan-sebatik-tengah1 (diakses tanggal 20 September 2019)

Berdasarkan data yang dapat dilihat, luas kecamatan di pulau Sebatik hanya 1,73 persen dari luas Kabupaten Nunukan seluruhnya, yakni 14.247,50 km2. Dari sisi posisinya dengan Malaysia, kecamatan sebatik utara, sebatik tengah, dan sebatik barat adalah tiga kecamatan yang bersebelahan langsung dengan Malaysia. Jarak ibukota kecamatan ke ibukota Kabupaten Nunukan adalah 21,40 km untuk Sebatik Utara, 18,41 km untuk Sebatik Tengah sedangkan Sebatik Barat jaraknya hanya 5,78 km saja. Hal ini disebabkan karena pusat pemerintahan kecamatan Sebatik Barat terletak di Binalawan yang dekat dengan gerbang masuk Pulau Sebatik. Tim peneliti pada saat penelitian mencoba meninjau langsung lokasi perbatasan Indonesia dengan Malaysia yang terletak di kecamatan Sebatik Tengah.

Berdasarkan pengamatan yang dilakukan peneliti, pos perbatasan Indonesia dengan Malaysia di Pulau Sebatik memiliki keunikan tersendiri, dimana terdapat beberapa rumah yang badan rumahnya terletak di dua wilayah negara. Bagian depan masuk ke wilayah Indonesia, sedangkan bagian belakang masuk ke wilayah Malaysia, hal mana merupakan kondisi aktual yang sudah lama terjadi. Kondisi tersebut selama ini diselesaikan secara musyawarah dan kekeluargaan selama tidak mengganggu kondisi keamanan masing-masing negara.

30 | SUSIOGLOBAL : Jurnal Pemikiran dan Penelitian Sosiologi, Vol. 4, №. I, Desember 2019 


\section{B. Perbatasan Wilayah \& Ancaman Keamanan Nasional}

Melihat kondisi letak geografis tiga Kecamatan di Pulau Sebatik yang secara langsung berbatasan dengan Malaysia, diperlukan penanganan secara serius akan sejumlah potensi ancaman keamanan dan ketahanan yang mungkin dapat terjadi. Secara umum perlu adanya penekanan mengenai pentingnya memperhatikan wilayah perbatasan. Hal ini sebagaimana diungkapkan Marwasta (2016) yang menjelaskan bahwa wilayah perbatasan memiliki nilai-nilai strategis diantaranya:

a) Daerah perbatasan sangat berpengaruh dalam mempertahankan kedaulatan negara.

b) Daerah perbatasan adalah faktor pendorong untuk meningkatkan kesejahteraan sosial dan ekonomi masyarakat sekitarnya.

c) Daerah perbatasan memiliki keterkaitan dengan wilayah yang berbatasan dengan wilayah tersebut yang satu sama lain saling mempengaruhi baik antar wilayah maupun antar negara

d) Daerah perbatasan memiliki pengaruh terhadap kondisi dan situasi pertahanan dan keamanan wilayah, baik dalam skala regional maupun skala nasional.

Selain itu, dengan berkembangnya zaman, ancaman terhadap keamanan dan pertahanan negara semakin mengalami perluasan dan pendalaman makna. Hal ini berarti bahwa keamanan dan pertahanan tidak lagi hanya berkaitan dengan soal militer atau aparat negara dalam melindungi dan mempertahankan suatu wilayah atau keamanan dan pertahanan tidak lagi hanya menempatkan negara sebagai aktor utama, keamanan melainkan harus juga melibatkan aktor lain selain negara seperti halnya individu dan kelompok masyarakat (Alfajri, Setiawan dan Wahyudi, 2019). Buzan B (1983), mengkritik tata cara keamanan tradisional yang dianggap terlalu state-centric dan military-centric dan kemudian membagi ke dalam lima hal yang seharusnya dilibatkan dalam menghadapi ancaman dan ketahanan negara. Kelima hal tersebut ialah: 1) militer, 2) lingkungan, 3) ekonomi, 4) sosial dan 5) politik.

Beberapa isu dan permasalahan yang berkaitan dengan pengelolaan kawasan perbatasan menurut Marwasta, dkk (2014) mencakup aspek- aspek sebagai berikut.: Kesatu, belum adanya kebijakan yang berpihak pada kawasan perbatasan dan daerah terisolasi. Kedua, strategi nasional pengembangan kawasan perbatasan belum efektif. Ketiga, masih terdapat pandangan mengenai kawasan perbatasan yang hanya dianggap sebagai halaman belakang (backyard) yang artinya belum menjadi prioritas utama negara dalam pengembangannya. Keempat, adanya kesenjangan sosial juga kesenjangan dalam kesejahteraan dengan penduduk yang menempati wilayah negara tetangga. Kelima, rendahnya akses ke wilayah perbatasan karena terbatasnya sarana dan 
prasarana wilayah. Keenam, rendahnya kualitas sumber daya manusia yang dimiliki. Ketujuh, banyaknya aktivitas illegal seperti halnya penyelundupan dan pelintas batas tradisional. Kedelapan, belum adanya kesepakatan batas-batas teritorial dengan negara tetangga seperti halnya Batas Laut Teritorial (BLT), Batas Landas Kontinen (BLK) dan Batas Zona Ekonomi Eksklusif (ZEE), Kesembilan, tidak terkendalinya eksploitasi sumber daya alam dan hal ini terus berkelanjutan. Kesepuluh, kerja sama hukum antarnegara belum terjadi secara optimal khususnya dalam masalah penanggulangan pelanggaran-pelanggaran yang terjadi di perbatasan. Kawasan perbatasan sebagai salah satu hal yang strategis khususnya bagi stabilitas keamanan, sosial, dan ekonomi. Pandangan geopolitik di Indonesia dikenal dengan istilah wawasan Nusantara. Pandangan ini dikembangkan dari teori wawasan nasional secara universal yang dijiwai serta dibentuk oleh paham kekuasaan bangsa Indonesia dan geopolitik Indonesia. Pandangan ini memiliki prinsip menciptakan persatuan bangsa dan keutuhan wilayah NKRI berdasarkan semangat Bhinneka Tunggal Ika dalam kerangka kesetaraan, keadilan, kebersamaan, dan kepentingan nasional. Konsep wawasan Nusantara tersebut sejalan dengan pandangan geopolitik Karl Houshofer tentang konsep lebensraum (ruang hidup) atau penjelasan Ratzel bahwa manusia sama dengan organisme yang memerlukan ruang hidup dan konsep autarki, yaitu cita-cita untuk memenuhi kebutuhan negara sendiri tanpa menggantungkan diri pada negara lain (Sunarso, dkk., 2008).

Pemerintah Indonesia juga sudah menyadari bahwa diperlukan aturan-aturan perbatasan untuk melindungi NKRI dari ancaman-ancaman dan tantangan pihak-pihak luar. Selain itu, Pemerintah Indonesia juga menyadari bahwa kondisi Indonesia merupakan negara maritim dengan jumlah pulau yang banyak dengan dikelilingi oleh negara-negara tetangga lain disekitar indonesia rentan menimbulkan permasalahan dalam hal pengaturan perbatasan. Oleh karena itu, Indonesia telah melakukan berbagai upaya perlindungan kawasan Nusantara diantaranya dengan membuat pasal 25 UUD 1945 tentang aturan wilayah negara dan kini telah juga diamandemen dengan penambahan-penambahan yang dianggap penting untuk melindungi keamanan dan ketahanan negara. Menurut Harjanti (2016) sebelum diamandemen dengan adanya Pasal 25 UUD45 ini sudah menghasilkan berbagai aturan hukum untuk melindungi kedaulatan negara di antaranya ialah:

\section{a) Undang-Undang}

1) Undang-Undang Nomor 1 Tahun 1973 tentang Landas Kontinen

2) Undang-Undang Nomor 5 Tahun 1983 tentang ZEE

3) Undang-Undang Nomor 17 Tahun 1985 tentang Pengesahan UNCLOS

4) Undang-Undang Nomor 6 Tahun 1996 tentang Perairan Indonesia

32 | SGSIOGLOBAL : Jurnal Pemikiran dan Penelitian Sosiologi, Vol. 4, o. I, Desember 2019 
5) Undang-Undang Nomor 43 Tahun 2003 tentang Wilayah Negara

6) Undang-Undang No.17 Tahun 2007 tentang Rencana Pembangunan Jangka Panjang Nasional (RPJPN) 2005-2025

\section{b) Peraturan Pemerintah:}

1) Peraturan Pemerintah Nomor 36 Tahun 2002 tentang Hak Lintas Damai

2) Peraturan Pemerintah Nomor 37 Tahun 2002 tentang Hak Lintas di ALKI

3) Peraturan Pemerintah Nomor 38 Tahun 2002 dan Peraturan Pemerintah Nomor 37

Tahun 2008 tentang Titik Koordinat

\section{c) Keppres/Perpres}

1) Keppres Nomor 178 Tahun 1999

2) Perpres Nomor 78 Tahun 2005

Hal yang telah dilakukan ini secara nyata merupakan bukti bahwa pemerintah Indonesia telah melakukan upaya-upaya strategis dalam mengatasi segala permasalahan yang mungkin timbul sebagai akibat dari perbatasan. Hal ini dilakukan tidak lain ialah untuk menjaga keamanan dan ketahanan negara republik Indonesia dari hal-hal yang tidak diinginkan. Hal ini sesuai dengan yang dikemukakan oleh Buzan (1983), bahwa negara merupakan pemeran yang sangat sentral dalam menangani masalah keamanan. Hal ini karena negara memiliki empat aspek yang tidak dimiliki oleh aktor lain, yaitu: 1) otoritas publik, 2) legitimasi, 3) kekuatan koersif, dan 4) mengelola kepatuhan. Empat aspek inilah yang membuat negara dapat menangani permasalahan-permasalahan keamanan baru yang sifatnnya nonmiliter namun berpotensi untuk mengganggu stabilitas keamanan negara dan keamanan masyarakat.

Pengertian keamanan memang seharusnya tidak berdiri sendiri, karena memiliki pengertian yang berbeda dan atribut tertentu. Pemahaman keamanan nasional yang komprehensif pada umumnya disertai dengan tututan untuk mengedepankan keamanan manusia (human security). isu-isu militer dan non militer tidak hanya mengacam keutuhan negara tetapi juga mengacam individu-individu yang berdiam di sebuah negara. Pada tahun 1990, PBB telah membangun dan mengembangkan konsep tentang keamanan manusia dengan karakteristik "...from an exclusive stress on national security to a much greater stress on people's security, from security through armaments to security through human development, from territorial to food, employment and environmental security" (UNDP dalam Rani, 2012). Selanjutnya UNDP (1994) membuat tujuh dimensi keamanan, yaitu:

a) Keamanan Ekonomi (economic security): dimana diperlukan pendapatan dasar dari pekerjaan produktif. 
b) Keamanan Pangan (food security): setiap orang pada setiap kesempatan memiliki akses (baik kesehatan dan ekonomi) terhadap panganan dasar.

c) Keamanan Kesehatan (health security): setiap orang harus dijamin kesehatannya dan akses untuk menuju sehat.

d) Keamanan Lingkungan: kesehatan dan ketertiban serta keamanan lingkungan secara fisik.

e) Keamanan Individu: pengurangan ancaman individu dari tindakan kejahatan.

f) Keamanan Komunitas: keamanan melalui keanggotaan dalam suatu kelompok.

g) Keamanan Politis: dijaminnya kehidupan dalam masyarakat yang menghargai hak asasi manusia.

Tujuh dimensi tersebut di atas, dijelaskan Siregar (2008) tidak berdiri sendiri, melainkan saling berkelindan satu dengan yang lainnya. Jadi jelas, negara memerlukan keamanan secara nasional dan menyeluruh untuk melindungi wilayahnya dari hal-hal yang tidak diinginkan. Dalam sudut pandang lebih luas Darmono dkk (2010) mengemukakan pengertian keamanan nasional sebagai "Kebutuhan dasar untuk melindungi dan menjaga kepentingan nasional suatu bangsa dan negara dengan menggunakan kekuatan politik, ekonomi dan militer untuk menghadapi berbagai ancaman baik yang datang dari luar maupun dari dalam negeri. Keamanan nasional juga dapat diartikan sebagai kebutuhan untuk memelihara dan mempertahankan eksistensi negara melalui kekuatan ekonomi, militer dan politik serta pengembangan diplomasi. Konsep tersebut menekankan kepada kemampuan pemerintah dalam melindungi integritas teritorial negara dari ancaman yang datang dari luar dan dari dalam negara tersebut.

Indonesia sebagai suatu negara-bangsa sudah diakui kedaulatannya secara internal maupun eksternal. Secara internal, kedaulatan suatu negara dapat dinyatakan secara formal dengan keberadaan wilayah beserta dengan penduduk dan pemerintahan di dalamnya. Secara eksternal, kedaulatan suatu negara ditunjukkan dengan adanya pengakuan (recognition) dari negaranegara lain. Secara demikian, wilayah perbatasan negara mempunyai peranan dan nilai strategis dalam mendukung tegaknya kedaulatan negara, sehingga pemerintah Indonesia wajib memperhatikan secara sungguh-sungguh kesejahteraan dan keamanan nasional. Wilayah perbatasan perlu mendapatkan perhatian karena kondisi tersebut akan mendukung keamanan nasional dalam kerangka NKRI. Adapun Buzan dalam Rani (2012) kemudian membuat lima kategori ancaman berdasarkan sektornya terhadap keamanan nasional, yaitu:

a) Ancaman militer. Secara tradisional ancaman militer merupakan prioritas tertinggi yang menjadi perhatian dari keamanan nasional, hal ini dikarenakan ancaman militer 
dengan menggunakan kekuatan bersenjata yang dapat memusnahkan apa yang telah di capai oleh manusia. Ancaman militer juga tidak hanya bersifat langsung, tetapi juga dapat tidak langsung ditujukan kepada negara itu, tetapi lebih kepada kepentingan-kepentingan eksternal yang ditujukan kepada negara itu.

b) Ancaman politik. Ancaman ini ditujukan kepada stabilitas kinerja institusi negara. Tujuan mereka cukup luas, dari mulai menekan pemerintah lewat kebijakan-kebijakan tertentu, penggulingan pemerintahan, menggerakkan kekacauan. Target dari ancaman politik ini adalah nilai-nilai negara, terutama identitas nasional, idiologi, dan beberpa institusi yang berurusan dengan ini. Ancaman politik juga dapat bersifat struktural, yang secara spesifik muncul ketika terjadi bentrokan antara dua kelompok besar dalam negara dengan pemikiran yang berbeda.

c) Ancaman sosietal. Ancaman sosial terhadap keamanan nasional biasanya datang dari dalam negeri. Keamanan sosial ialah mengenai ancaman terhadap keberlanjutan dari perubahan nilai, budaya, kebiasaan, identitas etnik. Masih menurut Buzan, ancaman sosietal dapat dibagi menjadi beberapa bentuk, yang secara mendasar yaitu: ancaman fisik (kematian, kesakitan), ancaman ekonomi (pengrusakan hak milik, terbatasnya akses lapangan kerja), ancaman terhadap hak- hak (pembatasan hak-hak kebebasan sipil), dan ancaman terhadap posisi atau status (penurunan pangkat, penghinaan di depan publik).

d) Ancaman ekonomi. Masalah utama dari ide tentang keamanan ekonomi adalah berlangsungnya kondisi normal dari aktor-aktor pelaku pasar tanpa gangguan persaingan tidak sehat dan ketidakpastian. Ancaman ekonomi juga mengkaji masalah pengangguran, kemiskinan, keterbatasan terhadap sumber daya, dan daya beli rakyat.

e) Ancaman ekologi. Merupakan ancaman dari bencana alam seperti banjir, longsor, hujan badai, gempa bumi. Namun yang menjadi isu sentral keamanan ekologi adalah masalah aktivitas manusia yang merusak lingkungan seperti pemanasan global, efek rumah kaca, banjir, eksplorasi sumber daya alam secara besar-besaran dan terus menerus.

\section{PEMBAHASAN}

Berdasarkan hasil penelitian di lapangan setelah melakukan berbagai upaya baik melalui observasi, wawancara dan focus group discussion. Persoalan keamanan wilayah perbatasan sampai saat ini masih menjadi masalah yang belum dapat diselesaikan, mengingat banyak aspek yang mesti dibenahi untuk dapat berjalan normal. Terdapat setidaknya tiga ancaman keamanan di perbatasan Indonesia-Malaysia yang sangat krusial untuk segera diselesaikan. Ketiga ancaman itu ialah ancaman bidang pertahanan dan keamanan atau ancaman militer, ancaman ekonomi, 
dan ancaman ideologi. Hasil identifikasi awal menemukan berbagai permasalahan sebagai berikut:

Ancaman pada bidang pertahanan dan keamanan atau ancaman militer berkaitan dengan beberapa persoalan yang harus diselesaikan, antara lain (1) masih minimnya anggaran untuk pengamanan perbatasan; (2) masih kurangnya jumlah personil (Polri) yang bertugas di wilayah perbatasan. Hal ini terlihat dari jumlah personil Polri di bawah ini:

Tabel 1. Kekuatan Personil Kepolisian di Pulau Sebatik

\begin{tabular}{clccc}
\hline \hline No & \multicolumn{1}{c}{ SATWIL } & POLRI & PNS & Jumlah \\
\hline \multirow{2}{*}{1} & Polsek Sebatik Timur & 26 & - & 26 \\
\cline { 2 - 5 } & $\begin{array}{l}\text { Polsubsektor Sungai } \\
\text { Taiwan }\end{array}$ & 4 & - & 4 \\
\hline 2 & Polsek Sebatik Barat & 18 & - & 18 \\
\cline { 2 - 5 } & Polsubsektor Aji Kuning & 2 & - & 2 \\
\cline { 2 - 5 } & Polsubsektor Bambangan & 2 & - & 2 \\
\cline { 2 - 5 } & Polsubsektor Setabu & 3 & - & 3 \\
\hline \multicolumn{2}{c}{ Jumlah } & 55 & - & 55 \\
\hline
\end{tabular}

Sumber: Sat Intelkam Polres Nunukan (2018)

Berdasarkan data di atas, jika dilihat dari ketersediaan personil yang ditempatkan di wilayah perbatasan, dapat dikatakan sangat kurang, mengingat wilayah yang harus dijaga dan potensi masalah yang muncul sangat besar. Selain di wilayah darat, pengamanan perbatasan juga dilakukan di wilayah laut, dalam hal ini dipegang oleh kepolisian perairan dan udara. Data personil yang bertugas menjaga wilayah perbatasan perairan dan udara di Kabupaten Nunukan dapat dilihat pada tabel berikut:

Tabel 2. Kekuatan Personil Kepolisian Perairan dan Udara di Propinsi Kalimantan Utara

\begin{tabular}{|c|c|c|c|c|c|c|c|c|c|}
\hline \multirow[b]{2}{*}{ KESATUAN } & \multicolumn{4}{|c|}{$\begin{array}{l}\text { POLR } \\
\end{array}$} & \multicolumn{4}{|c|}{ PNS/PH } & JML \\
\hline & PMN & PM & $\mathrm{BA}$ & TA & $\begin{array}{c}\text { GOL } \\
\text { I }\end{array}$ & $\begin{array}{c}\text { GOL } \\
\text { II }\end{array}$ & $\begin{array}{c}\text { GOL } \\
\text { III }\end{array}$ & PHL & \\
\hline Mako Dit Polairud & 3 & 4 & 21 & 6 & - & - & - & & 34 \\
\hline JUMLAH & 3 & 4 & 21 & 6 & - & - & - & - & 34 \\
\hline
\end{tabular}

Sumber: Direktorat Kepolisian Perairan dan Udara Kalimantan Utara (2019)

Selain itu, masih banyak pelintas batas ilegal. Hal ini disebabkan karena masih banyak titik-titik yang memiliki jalur "tikus". Terkait dengan tindak kejahatan yang muncul di wilayah perbatasan, berdasarkan penuturan personil yang bertugas di pos-pos perbatasan, tindak kejahatan yang mendominasi wilayah perbatasan adalah penyelundupan narkotika melalui jalur-jalur tikus di 
wilayah perbatasan Indonesia-Malaysia. Narkotika masih menjadi masalah besar di wilayah perbatasan Indonesia- Malaysia, khususnya yang banyak terjadi di Pulau Sebatik. Para penyelundup biasanya memanfaatkan jalur tikus untuk memasukkan narkoba ke Indonesia. Sulitnya memutus mata rantai penyelundupan narkoba dikarenakan penyelundup dari Malaysia biasanya memilih tempat di wilayah Malaysia, hal mana berakibat tidak dapat dilakukan penangkapan, karena bukan merupakan wilayah tugas dari Kepolisian Republik Indonesia.

Pada bidang ekonomi, masalah yang muncul adalah pemenuhan kebutuhan sehari-hari (sembako, sabun, dll) masih mengandalkan barang dari Malaysia, karena jarak dan biaya yang dikeluarkan masyarakat cenderung lebih murah jika dibandingkan dengan membeli barangbarang kebutuhan pokok dari Nunukan. Selain itu, masalah lain yang muncul ialah hal yang berkaitan dengan ketenagakerjaaan. Setidaknya terdapat tiga permasalahan yang sering muncul berkaitan dengan Tenaga Kerja Indonesia di Tawau. Kesatu, banyaknya pekerja Indonesia yang memiliki masalah keimigrasian, khususnya bagi pekerja yang mengalami penahanan passport oleh majikannya. Kedua, tidak dibolehkannya cuti/pulang sebelum kontrak selesai (biasanya 23 tahun). Bila ada keperluan, maka TKI terpaksa meninggalkan pekerjaannya tanpa sepengetahuan majikan. Akibatnya, TKI tersebut pulang tanpa membawa passport (dokumen) yang dapat menimbulkan masalah di keimigrasian. Ketiga, jenis pekerjaan yang diberikan ketika sampai di tempat kerja di Malaysia tidak sesuai dengan apa yang dijanjikan ketika di Indonesia (misalnya; di Indonesia dijanjikan bekerja di Restoran, namun ketika sudah sampai di tempat kerja di Malaysia, pekerja tersebut diminta bekerja "memotong babi", sedangkan ia beragama muslim yang notabene merupakan hal yang terlarang di agama Islam).

Pada bidang ideologi, potensi lunturnya kebanggaan terhadap Indonesia oleh karena masih banyak masalah pemenuhan kebutuhan hidup yang belum terselesaikan. Persoalan di hampir seluruh wilayah perbatasan selama ini tidak jauh dari persoalan ekonomi yang belum terselesaikan. Jika tidak segera dicarikan solusi, maka lambat laun dapat mengikis nasionalisme dan rasa bangga terhadap Indonesia bagi masyarakat yang tinggal di wilayah perbatasan. Desakan kebutuhan ekonomi mendorong para pekerja dari Indonesia untuk berbondong-bondong ke Malaysia, karena secara ekonomi bekerja di perkebunan sawit di Malaysia lebih menggiurkan dibandingkan bekerja di perkebunan sawit di Indonesia. Penghasilan pekerja Indonesia di Malaysia (Tawau) dihitung dari banyaknya (tonase) buah kelapa sawit yang diambil setiap harinya. Rata-rata pekerja yang bekerja di perkebunan kelapa sawit di Tawau dapat mengantongi uang 350.000-400.000/hari. Hal ini yang mendorong banyak orang Indonesia berpindah kewarganegaraan menjadi warga negara Malaysia. 
Berdasarkan hasil telaah yang dilakukan tim peneliti terhadap beberapa fenomena di wilayah perbatasan. Berbagai persoalan keamanan nasional yang dihadapi masyarakat di wilayah perbatasan disebabkan oleh beberapa hal. Kesatu, daerah di wilayah perbatasan pada umumnya merupakan daerah dengan masyarakat yang terbelakang, terutama dari aspek kualitas sumber daya manusia. Kedua, masih rendahnya kualitas sumber daya manusia di wilayah perbatasan memicu berbagai potensi konflik, baik horizontal maupun vertikal. Ketiga, belum terselesaikannya kesepakatan beberapa batas wilayah negara turut serta memicu konflik horizontal diantara masyarakat wilayah perbatasan kedua negara. Keempat, rendahnya sense of security pemerintah daerah serta masalah imigrasi dan kependudukan yang belum tertata dan terdokumentasikan dengan baik.

\section{SIMPULAN}

Berdasarkan hasil pengumpulan data dan analisis yang dilakukan maka dapat disarikan beberapa persoalan yang muncul di wilayah perbatasan Indonesia-Malaysia di Pulau Sebatik. Kesatu, tingginya penyelundupan narkotika terutama melalui jalur-jalur tikus, hal ini terjadi karena minimnya pengawasan yang disebabkan kurangnya jumlah personil keamanan (TNI dan Polri) yang bertugas di wilayah perbatasan. Kedua, kebijakan ekonomi belum sepenuhnya berpihak pada wilayah perbatasan di Pulau Sebatik, dimana untuk memenuhi kebutuhan hidup seharihari, masyarakat masih bergantung ke Malaysia. Dalam hal ini, pemerintah perlu mengambil kebijakan khusus untuk masyarakat di wilayah perbatasan, misalnya; subsidi harga bahan makanan pokok, sehingga masyarakat memilih untuk membeli produk dalam negeri dibandingkan ke luar negeri (Malaysia). Disamping itu, kebutuhan tersebut juga membuat masyarakat yang tinggal di perbatasan Pulau Sebatik merasa diperhatikan oleh negara, karena kebutuhan pokoknya pun diperoleh dari negara. Ketiga, berkaitan dengan ideologi, potensi lunturnya kebanggaan terhadap Indonesia di daerah perbatasan sangat tinggi. Hal ini disebabkan karena masih banyak masalah pemenuhan kebutuhan hidup yang belum terselesaikan. Persoalan di hampir seluruh wilayah perbatasan selama ini tidak jauh dari persoalan ekonomi yang belum terselesaikan. Jika tidak segera dicarikan solusi, lambat laun dapat mengikis nasionalisme dan rasa bangga terhadap Indonesia bagi masyarakat yang tinggal di wilayah perbatasan. Desakan kebutuhan ekonomi mendorong para pekerja dari Indonesia untuk berbondong-bondong pindah ke Malaysia, karena secara ekonomi Malaysia lebih menggiurkan dibandingkan Indonesia.

Berangkat dari sejumlah simpulan di atas, maka diperlukan perencanaan yang matang dan terintegrasi dalam mengatasi segala permasalahan yang terjadi di wilayah perbatasan yang dalam praksisnya melibatkan seluruh stakeholder intansi Pemerintahan Indonesia maupun pihak negara 
tetangga dengan melibatkan masyarakat sebagai aktor utamanya dalam upaya menguatkan keamanan di wilayah perbatasan. Selain itu, di era kemajuan teknologi informasi yang semakin massif saat ini, maka perlu dirancang suatu model pengamanan perbatasan melalui pemanfaatan teknologi yang berkelindan dengan system sosial budaya yang berkembang di lingkungan masyarakat. Model keamanan yang dilakukan tidak hanya hard power dan soft power, melainkan smart power yakni kolaborasi antara prosperity approach dengan security approach melalui sinergi pentahelix (pemerintah, akademisi, sektor swasta, masyarakat, dan media)

\section{DAFTAR PUSTAKA}

Alfajri, Azhari Setiawan, Herry Wahyudi. (2019). Sinergitas Pembangunan Tata Ruang Pertahanan Daerah dalam Menghadapi Ancaman Non-Militer di Indonesia. Jurnal Global \& Strategis, Th. 13, No. 1

Buzan, Barry. (1983). People, State, and Fear: The National Security Problem in International Relations. Brighton/Sussex: Wheatsheaf Books.

Darmono, dkk. (2010). Keamanan Nasional, Polisi, dan Intelijen Keamanan (Intelkam) Media Cabya Suryana (http://csuryana.wordpress. com/2013/04/15/keamanan-nasional-polisi-danintelijen-keamanan- intelkam-literature-review/)

Harjanti, Dewi K. (2016). Sengketa Perbatasan Indonesia-Malaysia: Sebuab Pertaruban Kedaulatan NKRI. JURNAL KAJIAN HUKUM Vol 1, No 1 (2016), Mei

Marwasta, Djaka. (2016). Pendampingan Pengelolaan Wilayah Perbatsan di Indonesia : Lesson Learned dari KKN-PPM UGM di Kawasan Perbatasan. (https://journal.ugm.ac.id/jpkm/article/view/10607/7989_)

Rani, Faisyal. (2018). Strategi Pemerintah Indonesia dalam Meningkatkan Keamanan Wilayah Perbatasan menurut Perspektif Sosial Pembangunan. (https://ejournal.unri.ac.id/index.php/JTS/article/view/79.)

Siregar, Chairil N. (2008). Analisis Potensi Daerab Pulau-Pulau Terpencil dalam Rangka Meningkatkan Ketahanan, Keamanan Nasional, dan Keutuban Wilayah NKRI di Nunukan-Kalimantan Timur. Bandung Jurnal Sosioteknologi ITB

Sugiyono. (2005). Memahami Penelitian Kualitatif. Bandung: CV. Penerbit Alfabeta.

UNDP. (1994). Human Development Report 1994. New York: Oxford University Press. 